\title{
Otwarcia
}

\section{Między aktywizmem a akademią. Studia nad niepełnosprawnością}

Magdalena Zdrodowska

TEKSTY DRUGIE 2016, NR 5, S. 384-403

DOI: $10.18318 /$ td.2016.5.25
Artykułpowstałw ramach projektu sfinansowanego ze środków Narodowego Centrum Nauki przyznanych na podstawie decyzji numer DEC-2014/15/D/ $\mathrm{HS} 2 / 03252$ - projekt Telefon, kino i cyborgi. Relacje rozwoju technologii $\mathrm{i}$ społeczności niesłyszqcych wXXiXXI wieku.
Problemem nie jest osoba niepełnosprawna. Problemem jest to, jak konstruowana jest normalność, by stworzyć „problem” osób niepełnosprawnych

Lennard Davis'

\section{Wprowadzenie}

Kontrkulturowe poruszenie przełomu lat 60. i 70. zaowocowało procesami emancypacyjnymi społeczności marginalizowanych zarówno w przestrzeni społecznej i politycznej, jak i refleksji akademickiej. Ich pokłosiem są gender studies, women's studies, minority studies czy queer studies. Rosemarie Garland-Thomson ${ }^{2}$ wymienione pola

1 L. Davis Enforcing Normalcy. Disability, Deafness, and the Body, Verso, London 1995, s. 24 .

2 R. Garland-Thomson Integrating Disability, Transforming Feminist Theory, w: The Disability Studies Reader, ed. L.J. Davis, Routledge, New York 2006, s. 333.

\section{Magdalena \\ Zdrodowska, dr, adiunkt w Instytucie Sztuk Audiowizual- nych Uniwersytetu Jagiellońskiego, czło- nek redakcji „Przeglą- du Kulturoznawcze- go" i „TransMissions". Autorka Telewizji na pograniczach (WUJ 2013). Etnolog i medioznawca, interesuje się historią technologii, relacjami między technologią a niepełnosprawny- mi. Kontakt: magda. zdrodowska@uj.edu. pl}


akademickiej refleksji obejmuje wspólnym terminem studiów nad tożsamością, wskazując na wspólne im zainteresowanie ciałem, w którym rzekomo niewinnie zagnieżdżona jest tożsamość, zakotwiczenie w teorii krytycznej z Foucaultowskim zestawem kategorii i pojęć oraz założenie o kulturowym skontekstualizowaniu kategorii normy i dewiacji. Na początku lat 9o. do wyżej wymienionych dziedzin dołączyły studia nad niepełnosprawnością (disabilitystudies) ufundowane na napięciu między medycznym i społecznym spojrzeniem na niepełnosprawność.

\section{Medyczny vs. społeczny model niepełnosprawności}

Źródła medycznego modelu niepełnosprawności można odnaleźć w XIX-wiecznej redefinicji kategorii normy oraz XX-wiecznej medykalizacji. Modernistyczna redefinicja normy, jakiej dokonało industrializujące się społeczeństwo zachodnie, zawiesiła funkcjonujący od starożytności wzorzec ciała, który jest nieosiągalnym dla śmiertelnika boskim ideałem ${ }^{3}$. Początek XIX wieku przynosi niezwykłą popularność statystyki i manię monitorowania - także żywych organizmów. Z tych obserwacji rodzi się idealny wzorzec przeciętnego człowieka - naukowo usankcjonowana norma ludzkiego ciała i psychiki, uśredniona wartość cech zmiennych w populacji, stająca się modelem, wedle którego oceniani są wszyscy jej członkowie. Norma ta była podobnie abstrakcyjna, jak starożytny ideał, ale jej społeczne funkcjonowanie było całkowicie odmienne: niegdysiejszy niedościgły wzór boskich ciał staje się imperatywem każdego człowieka. Odstępstwo od normy przestaje być traktowane jak naturalny stan rzeczy, świadectwo różnorodności ludzkiej natury, a zaczyna być postrzegane jako dewiacja. Francis Galton, bodaj najsłynniejszy XIX-wieczny eugenik i statystyk (profesje te nierzadko szły w parze), opracował paraboliczny wykres rozkładu normalnego, obrazujący rozkład normy i dewiacji w populacji. Nieczuła na kulturowe preferencje statystyka w kategorii dewiacji umieszczała jednak wszystkie odstępstwa od normy, Galton musiał zatem zaingerować w ów neutralny i przezroczyście naukowy model, by dewiacyjnej interpretacji nie zyskały aberracje pozytywnie traktowane w zachodniej kulturze, jak wysoki wzrost czy inteligencja. Ta, wydawać mogłoby się, transparentna i bazująca na ścisłych obliczeniach hegemonia wspólnej i pozornie nienegocjowalnej sztancy towarzyszyła industrializacji i usankcjonowaniu dominacji klasy średniej, a jednocześnie 
zachęcała państwo do praktyk dyscyplinujących i procedur normalizujących - w szczególności w sferze zdrowia.

Za konsekwencję tego procesu można uznać XX-wieczną medykalizację, którą Peter Conrad definiuje jako „ekspansję medycznej jurysdykcji”“. Oto zjawiska niegdyś uznawane za naturalne i niewymagające medycznej interwencji (strach, zmienne nastroje, poród czy śmierć) są definiowane w kategoriach medycznych, opisywane przy użyciu medycznego języka, określane za pomocą medycznych kategorii i w końcu „leczone”5. Owa medyczna jurysdykcja została rozciągnięta także na zjawiska postrzegane wcześniej jako grzech czy przestępstwo, jak pedofilia - Conrad pisze o przesunięciu „od zła ku chorobie” ("from badness to sickness”)

Medykalizacja każe także niepełnosprawność rozpatrywać w kategoriach choroby, co rodzi medyczny model niepełnosprawności i ma poważne konsekwencje zarówno w zakresie społecznych praktyk, jak i indywidualnych biografii. W modelu tym niepełnosprawność jest stanem skrajnie niepożądanym, utożsamionym z cierpieniem, dlatego też medycyna jest uprawniona do podejmowania wszelkich działań normalizujących niepełnosprawne ciało, żadna bowiem procedura medyczna (nawet bolesna czy obarczona ryzykiem) nie jest tak straszna, jak pozostawanie w stanie niepełnosprawności. Jak wskazuje Susan Sontag, cierpienie jest postrzegane jako motyw usprawiedliwiający strategie jego redukcji, nawet, gdy budzą one wątpliwości natury etycznej’ ${ }^{7}$ Leczenie, nawet gdy uciążliwe, jest usprawiedliwionym moralnie mniejszym złem, każda bowiem droga, by ulżyć cierpieniu, jest słuszna.

Medyczny model patologizuje zatem niepełnosprawność jako odstępstwo od normy i chorobę. Obydwa te stany są niepożądane zarówno ze społecznego, jak i indywidualnego punktu widzenia. Konsekwencją obydwu są działania naprawcze: normalizacja i leczenie. Osoby niewpisujące się w normę, posiadający „zespoły” i „syndromy” zostają zamienione w pacjentów. Najistotniejszym jednak założeniem modelu medycznego jest przyjęcie, że źródłem cierpienia jest konkretne niepełnosprawne ciało, można mu zatem

\footnotetext{
4 P. Conrad The Medicalization of Society: on the Transformation of Human Conditions Into Treatable Disorders, Johns Hopkins University Press, Baltimore-London 2007, s. 3.

5 Tamże, s. 5; cudzysłów autora.

6 Tamże, s. 6.

7 S. Sontag Widok cudzego cierpienia, Karakter, Kraków 2010.
} 
zaradzić przez indywidualnie dla każdego ciała postawioną diagnozę i zaordynowane leczenie lub rehabilitację. Medyczny model źródło problemu widzi w jednostce i jej indywidualnej kondycji, a nie warunkach społecznych czy kulturowych.

Problem pojawia się, gdy poddawani leczeniu i rehabilitacji - słowem normalizacji - pacjenci nie postrzegają swojej niepełnosprawności jako źródła cierpienia. Właśnie z tego pęknięcia wyrasta społeczny model niepełnosprawności i będące jego konsekwencją studia nad niepełnosprawnością, dla których model medyczny jest potężnym, ale też wygodnym i konsolidującym wrogiem ${ }^{8}$.

$\mathrm{Na}$ początku lat 70. XX wieku na Zachodzie pojawiają się radykalne organizacje skupiające osoby z niepełnosprawnościami i zwracające uwagę na

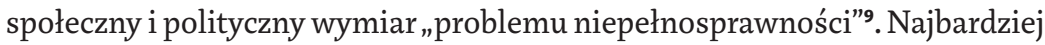
znaczącą z nich okazała się brytyjska UPIAS - Union of Physically Impaired

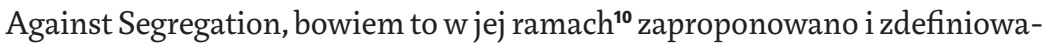
no społeczny model niepełnosprawności ${ }^{11}$, zabezpieczając intelektualne i polityczne zaplecze ruchu niepełnosprawnych. Dla działności UPIAS kluczowe były dwie osoby: aktywistycznej i politycznej energii dostarczał jej Paul Hunt, a o koncepcyjną i intelektualną stronę dbał Vic Finkelstein.

Paul Hunt, u którego zdiagnozowano dystrofię mięśniową, w młodości był mieszkańcem ${ }^{\mathbf{1 2}}$ Le Court - progresywnego, rodzinnego domu pomocy dla osób (nie tylko z niepełnosprawnościami), które nie mogły pozostawać w szpitalach, ale nie miały możliwości powrotu do domu. Doświadczenie funkcjonowania w instytucji opiekuńczej miało kolosalny wpływ na jego

8 Peter Conrad wskazuje, że jedną z przyczyn medykalizacji był humanitarny zwrot w społeczeństwach Zachodu, a objęcie niektórych kondycji "medyczną jurysdykcją" było procesem pozytywnym (np. alkoholizm), a czasami wywalczonym przez samych pacjentów (np. AIDS przez gejów i lesbijki, zespół stresu pourazowego przez weteranów z Wietnamu czy PMS przez ruchy kobiece).

9 K. Tanaka The Roots of the Social Model: A Life History of Paul Hunt, document online: http://disability-studies.leeds.ac.uk/files/library/Tankana-Life-history-of-Paul-Hunt1.pdf(8.11.2016).

10 Dokumenty: Union of the Physically Impaired Against Segregation: Policy Statement (1974), Fundamental Principles of Disability (1975).

Organizacja nie posługiwała się tym terminem, użył go Mike Oliver w książce Social Work with Disabled People (Macmillan 1983), by opisać nowe podejście do niepełnosprawności; podaję za: T. Shapespeare The Social Model of Disability, w: The Disability Studies Reader, s. 198. 
postawę życiową i poglądy. Hunt brał udział w samoorganizowaniu się mieszkańców, wchodził w otwarte konflikty z zarządzającymi, gdy wolność mieszkańców usiłowano ograniczać. Angażował się w działania organizacji wspierających osoby niepełnosprawne, brał udział w akcjach bezpośrednich i poddawał je krytyce, gdy zawłaszczali je pełnosprawni eksperci pracujący „dla niepełnosprawnych"13. Hunt głosił potrzebę powołania do życia organizacji, która byłaby zarządzana przez samych niepełnosprawnych. Rok po opuszczeniu Le Court, w 1971 roku, opublikował w „The Guardian” manifest postulujący powołanie stowarzyszenia niepełnosprawnych - co interesujące - konsumentów. Założony przez niego w 1973 roku UPIAS miał zwalczać segregację dokonującą się właśnie za pośrednictwem wyspecjalizowanych instytucji gromadzących osoby z niepełnosprawnościami, w nich samych chciał zapewnić mieszkańcom niezależność i samostanowienie, promował zrzeszanie się niepełnosprawnych i koncentrował się na kwestii ich finansowej niezależności.

Vic Finkelstein, podobnie jak Hunt, poruszał się na wózku inwalidzkim. Pochodził z Republiki Południowej Afryki, skąd w 1968 roku uciekł prześladowany za działania przeciwko apartheidowi. To kolejne, indywidualne, mocne doświadczenie, które naznaczyło UPIAS: praktyki i idee wyniesione z walki o równouprawnienie w RPA okazywały się zaskakująco aktualne w realiach rodzącego się ruchu niepełnosprawnych. Wpływ ten ujawnia nazwa UPIAS, posługująca się kategorią segregacji, ale przede wszystkim założenie, że niepełnosprawność, jak rasa, jest kategorią społecznie konstruowaną i reprodukowaną, a nie konsekwencją naturalnego porządku. Finkelstein wprowadza do dyskursu ruchu kategorię opresji i inspirację marksistowską myślą krytyczną. On też - psycholog, naukowiec - był łącznikiem społecznego ruchu niepełnosprawnych ze światem akademickim. Brał udział w przygotowaniach pierwszego akademickiego kursu dotyczącego polityki niepełnosprawności na Open University (Wielka Brytania). Wraz z Mike'em Oliverem i Colinem Barnesem stanowili pierwszą falę naukowców badających kwestie związane z niepełnosprawnością, naznaczyli dziedzinę aktywistycznym zacięciem: koncentracją na dokumentacji współczesnych i historycznych przejawów opresji oraz proponowaniem rozwiązań (nie tylko społeczno-politycznych), które mogłyby temu przeciwdziałać.

13 P. Hunt Settling Accounts with the Parasite People: A Critique of "A Life Apart" by E.J. Miller and G.V. Gwynn, "Disability Challenge” 1981 No. 1, s. 37-50. 
W 1975 roku UPIAS ${ }^{\mathbf{1 4}}$ proklamował nowe rozumienie niepełnosprawności: „to społeczeństwo upośledza niepełnosprawnych. Niepełnosprawność (disability) narzucana jest na nasze upośledzenia (impairments) przez niepotrzebna izolację i wykluczenie z pełnego uczestnictwa w życiu społecznym. Sprawia to, że niepełnosprawni są poddawaną opresji grupą społeczną"15. Tym zdaniem kładzie kamień węgielny pod studia nad niepełnosprawnością: rozdzielenie niepełnosprawności i upośledzenia. Jest to podział binarny, podobny do tego, w którym w ramach teorii feministycznej funkcjonują kategorie płci biologicznej (sex) i kulturowej (gender). Upośledzenie jest esencjonalnie związane z ciałem i jego kondycją. Jest faktem zastanym, naturalnym i niepodlegającym praktykom dyskursywnym czy koncepcyjnym. Niepełnosprawność zaś definiowana jest jako dynamicznie rozgrywająca się w przestrzeni społecznej reakcja na upośledzenie.

Zarzewiem zarówno społecznego modelu niepełnosprawności, jak i studiów nad niepełnosprawnością był oddolny aktywizm niepełnosprawnych. Uwiarygadniało to studia, nadawało im energii i ukierunkowywało zainteresowania,jednak miało także poważne wady. Społeczny model posługiwał się uproszczonym obrazem świata: wyraźnie wskazywał winowajców, obiecywał utopijną wizję świata bez barier, proponował sloganową, niewytrzymująca krytyki definicję niepełnosprawności jako opresji samej w sobie. W 2004 roku Mike Oliver, jeden z ojców założycieli studiów nad niepełnosprawnością, przyznał, że społeczny model niepełnosprawności jest raczej „użytecznym narzędziem niż teorią, ideą czy pojęciem"16. Jak zauważa Tom Shakespeare ${ }^{\mathbf{1 7}}$, to, co doskonale działa na sztandarach, nie sprawdza się jako podwalina dyskursu akademickiego, a tym bardziej narzędzie opisu rzeczywistości. Szybko okazało się, że obraz niepełnosprawności przyjęty przez poruszających się na wózkach inwalidzkich założycieli nie odpowiada niepełnosprawnościom innym niż związane z ograniczeniem mobilności. W wielu przypadkach nie sposób bowiem wyraźnie oddzielić społecznie generowanej niepełnosprawności od pochodzącego z ciała upośledzenia - np. chroniczny ból bardzo istotnie zmienia życie człowieka, niezależnie od społecznych postaw

\footnotetext{
14 Podaję za T. Shapespeare The Social Model of Disability, s. 198.

15 Podajęza tamże.

16 M. Oliver The Social Model in Action: If I Had a Hammer, w: Implementing the Social Model of Disability: Theory and Research, eds. C. Barnes, G. Mercer, The Disability Press, Leeds 2004, s. 19.

17 T. Shapespeare The Social Model of Disability, S.199.
} 
i praktyk. Model społeczny w zasadzie zaprzecza wpływowi upośledzenia na życie człowieka i przenosi moralną odpowiedzialność za cierpienie niepełnosprawnych na opresyjne społeczeństwo ${ }^{18}$, tymczasem wielu niepełnosprawnych deklaruje, że ich upośledzenie ma dla nich ogromne znaczenie, z którego nie chcą rezygnować.

Społeczny model niepełnosprawności spotkał się z krytycznym odzewem szczególnie środowisk feministycznych - ta tradycja intelektualna wcześniej odrobiła lekcję nadmiernie upraszczającego binarnego podziału sex/naturalne - gender/kulturowe. W latach 90. pojawiła się fala tekstów poddających go krytyce ${ }^{19}$, zaś w 2005 roku Shelly Tremain, posługując się Foucaultowskimi kategoriami biowładzy i technologii urządzania, wyraźnie wskazała, że upośledzenie nie jest wcale transparentnym i obiektywnym stanem, na którym kulturowo i społecznie nadbudowuje się niepełnosprawność, ale samo również jest historycznie, społecznie i kulturowo skontekstualizowane ${ }^{20}$. Przyjęcie przez studia nad niepełnosprawnością podziału na niepełnosprawność i upośledzenie sprawiło, że silnie postulowana przez nie demedykalizacja dotyczyła tylko niepełnosprawności, uznając upośledzenie za stan naturalny. Tremain twierdzi, że ów sztuczny podział, odpowiadający podziałowi kultura - natura, jest nie do utrzymania - aby uznać kogoś za niepełnosprawnego, jego ciało musi być upośledzone. Jednocześnie autorka, wskazując na praktyki normalizujące, pisze, że upośledzenie także jest społecznie wytwarzane, jako służące bieżącym rozwiązaniom politycznym. Studia nad niepełnosprawnością, przyjmując upośledzenie jako coś naturalnego i transparentnego, paradoksalnie utwierdzają i przedłużają działanie systemu przeciw któremu występują̨

W odpowiedzi na te zarzuty, a także na rodzące się na początku XXI wieku, głównie w Stanach Zjednoczonych, zainteresowanie niepełnosprawnością ze strony humanistyki i sztuki oraz coraz bardziej palącą potrzebę

18 Tamże.

19 M.in.: J. Morris Pride Against Prejudice, Women's Press, London 1991; S. French Disability, Impairment or Something in Between, w: Disabling Barriers, Enabling Environments, ed. J. Swain i in., Sage, London 1993; L. Crow Renewing the Social Model of Disability, "Coalition" 1992, July, s. 5-9; wybór za T. Shapespeare The Social Model of Disability, s. 201.

S. Tremain Foucault, Governmentality, and Critical Disability Theory, w: Foucault and the Government of Disability, ed. S. Tremain, The University of Michigan Press, Ann Arbor 2005.

21 S. Tremain On the Government of Disability. Foucault, Power, and the Subject of Impairment, w: The Disability Studies Reader, s. 192. 
odseparowania akademików od wykorzystujących społeczny model polityków i działaczy ${ }^{22}$ wyłaniają się krytyczne studia nad niepełnosprawnością - critical disability studies. W ich ramach Mairian Hill Scott ${ }^{23}$ zaproponowała odejście od dychotomicznego podziału upośledzenie - niepełnosprawność i definiowania niepełnosprawności jako tożsamościotwórczego, zbiorowego doświadczenia opresji, na rzecz badania relacji między upośledzeniem i dyskryminacją. Simo Vehmas i Nick Watson, odwołując się do Foucaultowskiej kategorii krytyki, zaproponowali skupienie się na mechanizmach kształtowania się relacji między osobami sprawnymi i niepełnosprawnymi, analizę pozornie przeźroczystych kategorii jako płynnych i społecznie kształtowanych. Krytyczne studia nad niepełnosprawnością mają być „bardziej refleksyjne i teoretycznie czujne"24, silnie inspirują się innymi krytycznymi dziedzinami podejmującymi zagadnienia rasy, etniczności czy płci - na kształt obowiązkowego heteroseksualizmu Adrienne Rich McRuer proponuje obowiązkową sprawność (compulsory able-bodiedness) ${ }^{25}$. Za charakterystyczne dla krytycznych studiów nad niepełnosprawnością uznaje się stawianie pytań o wymiar aksjologiczny związany z normatywnością i niepełnosprawnością: co jest dobre, właściwe i etyczne ${ }^{26}$.

\section{Między aktywizmem a akademią - badania emancypacyjne}

Studia nad niepełnosprawnością lokują się między refleksją naukową a społecznym i politycznym aktywizmem, gdzie pełnią rolę krytyczną (wskazując na opresję, dążąc do zmian legislacyjnych i zmiany postaw społecznych) oraz emancypacyjną. W obydwu tych sferach wyrastają z politycznej aktywności i emancypacji niepełnosprawnych, dzieląc ścieżkę rozwoju z dziedzinami takimi jak african-american studies, women's studies czy queer studies. Dlatego, mimo

22 Journal of Human Rights" 2009 No. 15 (1), s. 47-75.

\footnotetext{
M. Corker Differences, Conflations and Foundations: The Limits to 'accurate' Theoretical Representation of Disabled People's Experiences, "Disability \& Society” 1999 No. 14 (5), s. 627-642; Deaf and Disabled or Deafness Disabled, Open University Press 1998.

S. Vehmas, N. Watson Moral Wrongs, Disadvantages, and Disability: a Critique of Critical Disability Studies, „Disability \& Society” 2014 No. 29:4, s. 640.

R. McRuer Compulsory Ablebodiedness and Queer/Disabled Existence, w: The Disability Studies Reader, ed. L.J. Davis, Routledge, New York-London 2013, s. 374.

S. Vehmas, N. Watson Moral Wrongs...
} 
że są dziedziną akademicką podejmującą rozważania nad rzeczywistością, są postrzegane także jako narzędzie wpływania na nią. Badają niesprawiedliwość i opresję osób z niepełnosprawnościami - współcześnie i w perspektywie historycznej - by wskazywać ścieżki postępowania na przyszłość, ale także wyprowadzają problematykę niepełnosprawności z zamkniętego kręgu medycyny, rehabilitacji i pomocy społecznej. Ambicja ingerencji w rzeczywistość wykroczyła poza tematykę badań i przybrała postać metodologicznego imperatywu badań emancypacyjnych.

Badania emancypacyjne bliskie są participatory oraz action research ${ }^{27}$, które angażują badanych w proces badawczy, a przez to włączają członków (najczęściej wykluczanych czy mniejszościowych) społeczności w działania należące do głównego nurtu. Badania emancypacyjne mają iść o krok dalej: kontrola nad nimi ma przypaść uczestnikom, mają nie tyle włączać wykluczonych, co tak zmieniać rzeczywistość, by znalazło się w niej dla nich miejsce. Kontrola badanych rozumiana jest szeroko: „tylko gdy niepełnosprawni lub ich organizacje są na szczycie badawczej hierarchii w tym kontrolują finansowanie badań - można powiedzieć, że badanie ma emancypacyjny charakter" ${ }^{\mathbf{2 8}}$. W tym paradygmacie badacze zostają zatem zamienieni w specjalistów do wynajęcia ${ }^{29}$. Sprawia to, że badania emancypacyjne stały się swoistym świętym Graalem studiów nad niepełnosprawnością - punktem docelowym, do którego jednak szalenie trudno dotrzeć.

Jednocześnie niepełnosprawność jest definiowana w kategoriach opresji, której jak twierdzi Mike Oliver, nie da się badać w „obiektywny, naukowy sposób” ${ }^{30}$. Barnes dodaje: „jesteś albo po stronie prześladowców albo poddawanych opresji"31. Od badacza wymaga się zatem jednoznacznej deklaracji i podaje w wątpliwość zasadność prowadzenia badań przez osoby

27 M. Oliver Emancipatory Research: Realistic Goal or Impossible Dream, w: Doing Disability Research, eds. C. Barnes, G. Mercer, The Disability Press, Leeds 1997.

E. Stone, M. Priestley Parasites, Pawns and Partners: Disability Research and the Role of Non-Disabled Researchers, "British Journal of Sociology” 1996 No. 47 (4), s. 699-716.

29 P. Ramcharan, G. Grant Setting One Agenda for Empowering Persons with a Disadvantage Within the Research Process, w: Disability is not Measles: New Research Paradigms in Disability, eds. M. Rioux, M. Bach, L'Institut Rœher, Ontario 1994, s. 237. 
sprawne. Jest to pytanie pojawiające się od women's przez minority po queer studies: na ile „inni” mogą porzucić swoją hegemoniczną pozycję (wzmacnianą jeszcze zazwyczaj przez procedurę badawcza), uzyskać wgląd w problemy badanych, najczęściej nieuprzywilejowanych społeczności. Paul Hunt nazywa pełnosprawnych badaczy pasożytami ${ }^{32}$, które wykorzystują niepełnosprawnych, by publikować książki i zdobywać stopnie naukowe ${ }^{33}$. Emma Stone i Mark Priestley w eseju Parasites, Pawns and Partners: Disability Research and the Role of Non-Disabled Researchers ${ }^{34}$ opisują możliwe wzory relacji między badaczami i badanymi niepełnosprawnymi i widzą szansę dla sprawnych badaczy (być może dlatego, że sami nimi są). Podobne przyzwolenie dają Colin Barnes i Geof Mercer ${ }^{35}$, dopuszczając badania prowadzone przez sprawnych badaczy, gdyż samo uczestnictwo w opresyjnym społeczeństwie daje doświadczenie i wgląd w proces społecznego uniesprawniania.

Emancypacyjny paradygmat badań stawia poprzeczkę badaczom tak wysoko, że w poświęconym mu tomie Doing Disability Research ${ }^{36}$ w niemal każdym rozdziale pojawia się wątpliwość, czy raportowane badania były emancypacyjne, a autorzy w starają się przede wszystkim dowieść owej emancypacyjności. O tym, jak trudno prowadzić tego typu badania czy chociażby zmienić własną perspektywę i wdrukowane ableistyczne postawy, może świadczyć rodzimy przykład. Autorki artykułu Studia nad niepełnosprawnością a wyobraźnia socjologiczna ${ }^{37}$, mimo że zdają się pracować w paradygmacie społecznego modelu niepełnosprawności i powołują się na niego jako ramę dla relacjonowanego w tekście projektu badawczego, mimo że deklarują emancypacyjny charakter swoich badań, w pierwszych zdaniach piszą:

Osoby z niepełnosprawnościami stanowią około 15\% światowej populacji (miliard ludzi). Niestety, odsetek ten gwałtownie wzrasta. Powiększająca

32 P. Hunt Settling Accounts...

33 E. Stone, M. Priestley Parasites, Pawns and Partners...

34 Tamże.

C. Barnes, G. Mercer Breaking the Mould? An introduction to doing disability research, w: Doing Disability Research.

37 Tamże. 
się liczba ludności, degradacja środowiska, złe warunki pracy, ale także lepsze techniki gromadzenia danych to tylko niektóre czynniki wpływające na te niepokojące statystyki. ${ }^{38}$

Użycie negatywnie nacechowanych określeń jest niekompatybilne z tożsamościowym, społecznym rozumieniem niepełnosprawności, które badaczki zdają się stosować. Podobnie używają wielkiej litery w zapisie „Głuchy”, sygnalizującą kulturową i tożsamościową identyfikację badanych, a jednocześnie posługują się przynależącym do dyskursu i modelu medycznego (przeciwko któremu występują) sformułowaniem „dysfunkcja słuchu”39.

Studia nad niepełnosprawnością wydają się najistotniejsze w tych momentach, gdy pluralizują dyskurs akademicki i angażują niepełnosprawnych badaczy - co jest zarówno elementem emancypacji, jak i znaczącym przesunięciem wizerunkowym. Obecność osób niepełnosprawnych pozwala zaistnieć nowym kategoriom i ocenie tego, co dzieje się w przestrzeni działań kulturowych, języka, ujawnia opresyjne i krzywdzące reprezentacje tam, gdzie mogłoby się wydawać, że nie dochodzi do nadużyć. Przykładem kategorii reprezentujących w refleksji akademickiej mniejszościową perspektywę wprowadzoną przez niepełnosprawnych są m.in. pojęcia ableismu, inspiracyjnego porno (inspiration porn) oraz narracyjnej protezy (narrative prosthesis).

\section{Alternatywne dyskursy: ableism}

Jak stwierdza Simi Linton ${ }^{40}$, jednym z podstawowych, emancypacyjnych działań, jakie muszą podejmować zarówno ruchy niepełnosprawnych, jak i studia nad niepełnosprawnością, jest wprowadzenie nowych kategorii, które pozwolą nazwać mniejszościowe doświadczenie. Jedną z podstawowych kategorii wprowadzonych przez studia nad niepełnosprawnością jest ableism $^{41}$ obejmujący całość działań opresyjnych i stygmatyzujących osoby niepełnosprawne. Słowo to wywodzi się od przymiotnika able oznaczającego

38 B. Kowalska i in. Studia nad niepełnosprawnościq a wyobraźnia socjologiczna, "Studia Socjologiczne" $2014 \mathrm{nr} 2$ (213), s. 225.

Tamże, s. 241.

S. Linton Reassigning Meaning, w: The Disability Studies Reader, 2006, s. 161.

Termin ten trudno przełożyć na język polski, zachowując jego oryginalną wymowę, dlatego pozostawiam go w oryginalnym brzmieniu. 
sprawność i w podobny sposób jak rasizm czy mizoginizm obejmuje zestaw dyskryminujących praktyk i postaw (świadomych i nieświadomych), jakie dominująca, sprawna część społeczeństwa przejawia wobec osób, które uznaje za niesprawne, premiując „sprawną” perspektywę. Jako kategoria analityczna wskazuje na opresję dokonującą się na poziomie regulacji prawnych, działań społecznych czy języka. Jak wskazuje Veronica Chouinard, ableism jako zestaw idei, praktyk, instytucji i społecznych relacji konstruuje ludzi niepełnosprawnych jako marginalizowanych Innych ${ }^{\mathbf{4 2}}$.

Ableism jest dynamicznym mechanizmem konstruowania normy dla ciała, behawioru, emocjonalności, a także narzędziem podziału i oddzielenia tych, którzy się w nią nie wpisują ${ }^{43}$. W tym kontekście niezwykle wyraźne są inspiracje studiów nad niepełnosprawnością zarówno myślą Michela Foucaulta i jego koncepcją biowładzy ${ }^{44}$, jak i Bruno Latoura i jego kategoriami translacji i puryfikacji ${ }^{45}$.

Fiona Kumari Campbell dokonuje jednak szczególnej wolty. W książce Contours of Ableism. The Production of Disability and Abledness ${ }^{\mathbf{4 6}}$ proponuje, by porzucić charakterystyczną dla studiów nad niepełnosprawnością ścieżkę definiowania ableismu jako zestawu norm, praktyk i barier stygmatyzujących niepełnosprawność (takie działania określa mianem disableismu) i niejako negatywowo przyjrzeć się produkcji, operacjonalizacji i podtrzymywaniu ableismu. Retorycznie pyta o to, co studia nad głuchotą (deaf studies) mówią nam o tym, czym jest słyszenie ${ }^{47}$.

Ableism stosunkowo szybko został rozpoznany i przyjęty - już w 1993 roku jego definicja znalazła się w Reader's Digest Oxford Wordfinder, gdzie został zdefiniowany jako uprzywilejowanie osób sprawnych (able-bodied) ${ }^{\mathbf{4 8}}$.

V. Chouinard Making Space for Disabling Difference: Challenges Ableist Geographies. Environment and Planning, "Society and Space" 1997 No. 15, s. 379-387; cyt. za F.K. Cambell Contours of Ableism. The Production of Disability and Abledness, Palgrave MacMillan, London 2009, s. 5.

Tamże, s. 6. Gdańsk 2010.

B. Latour Nigdy nie byliśmy nowocześni: studium z antropologii symetrycznej, przeł. M. Gdula, Oficyna Naukowa, Warszawa 2011.

F.K. Cambell Contours of Ableism...

Tamże, s. 4 . 


\section{Alternatywne dyskursy: inspiration porn}

Kategoria inspiration porn jest krytyczną oceną reprezentacji osób niepełnosprawnych w codziennym oraz medialnym dyskursie. Propagatorką tego pojęcia była Australijka Stella Young - dziennikarka, komik i aktywistka ruchu osób niepełnosprawnych. Young na skutek wrodzonej łamliwości kości przez całe życie używała wózka inwalidzkiego. Po raz pierwszy oficjalnie użyła kategorii inspiration porn $\mathrm{w}$ tekście We Are Not Here for Your Inspiration ${ }^{49}$, a spopularyzowała je w wykładzie zaprezentowanym w ramach TED I Am Not Your Inspiration, Thank You Very Much w 2014 roku $^{50}$. Mianem inspiration porn Young określiła teksty, w których osoby niepełnosprawne obdarzane są wyrazami uznania jako „dzielnie”, „mimo przeciwności” radzące sobie z codziennością, która urasta do rangi wyzwania. Ich „zmagania” są dla osoby afirmującej motywacją i inspiracją do sprawniejszego radzenia sobie z problemami oraz docenienia własnej uprzywilejowanej pozycji. Young odnosi się przede wszystkim do tekstów medialnych, a szczególnie viralowo rozprzestrzenianych w mediach społecznościowych memów motywacyjnych. W warstwie wizualnej przedstawiają one osoby niepełnosprawne, często dzieci, wykonujące zupełnie zwyczajne czynności (jak zabawa, bieganie, rysowanie) oraz podnoszące na duchu przesłanie. Young odwołuje się do popularnych memów z mottem Scotta Hamiltona (byłego łyżwiarza figurowego, borykającego się z nawrotami choroby nowotworowej): „Jedyną niepełnosprawnością jest złe nastawienie" (the only disability in life is a bad attitude) czy "twoja wymówka jest ułomna" (your excuse is invalid). Zarówno w sferze ikonicznej, jak i językowej następuje odwołanie do niepełnosprawności, w czym nie byłoby nic niewłaściwego, gdyby nie to, że adresatami przekazu są osoby sprawne. To na nich obraz dziecka stojącego na protetycznych nogach i towarzyszące mu hasło mają wywrzeć wrażenie i im służyć. Emocjonalną reakcją na taki przekaz jest wdzięczność za własną kondycję fizyczną - nawet kiedy nie jest ona w pełni satysfakcjonująca, jest lepsza niż osoby poruszającej się na wózku inwalidzkim czy pozbawionej kończyn. Pojawia się ulga oraz współczucie wynikające z założenia, że życie osoby niepełnosprawnej jest godne pożałowania. Beth Haller i Jeffrey Preston, podejmując myśl Young, kwalifikują

\footnotetext{
49 S. Young We're Not Here for Your Inspiration, 2012, http://www.abc.net.au/news/2012-07-03/ young-inspiration-porn/4107006 (10.08.2016).

50 S. Young I Am Not Your Inspiration, Thank You Very Much, 2014 http://www.ted.com/talks/stella_young_i_m_not_your_inspiration_thank_you_very_much?language$=$ en (10.08.2016).
} 
inspiration porn jako narrację litości (pity narrative): sprawna osoba czuje się lepiej, współczując niepełnosprawnej, jeśli jednocześnie postrzega ją jako inspirującą ${ }^{51}$. Niepełnosprawność, jest przedstawiana jako stan tak straszny, że wykonywanie nawet najprostszych, codziennych czynności urasta do rangi heroizmu. Już sama niepełnosprawna egzystencja czyni wyjątkowym. Swoją mowę w czasie TED Stella Young kończy słowami: „Chciałabym żyć w świecie, w którym oczekiwania wobec niepełnosprawnych nie są tak niskie, że gratuluje się nam, że wstaliśmy z łóżka i pamiętamy, jak mamy na imię"52.

Young dokonuje trawestacji wcześniejszej kategorii superkaleki (supercrip) Clogstona $^{53}$, opisującego za jej pomocą wizerunek osoby niepełnosprawnej, która nadludzkim wysiłkiem przezwycięża niepełnosprawność, by prowadzić „normalne życie”. Posłużenie się słowem „kaleka”, zarzuconym jako niepoprawne politycznie i obraźliwe, czy „porno” odnoszącym do sfery erotyki jest nieprzypadkowe. Ruchy aktywistyczne nierzadko przekraczają tabu i piętrza transgresję, by wskazać wyraźnie i dobitnie na zjawiska, które są odczuwane jako opresja i nadużycie. Kategoria porno ujawnia eksploatacyjny charakter pozornie pozytywnego przekazu. Niepełnosprawni zostają wystawieni na widok i wykorzystani do wywołania emocji, których beneficjentami są wyłącznie sprawni widzowie. Stają się obiektem inspiracji, tak jak aktorzy porno są obiektem pożądania - w obydwu przypadkach podmiotowością obdarzeni są oglądający. Dzięki inspiration porn ich problemy i bolączki mają zyskać nową wymowę: mogło być gorzej.

Stella Young wskazuje, że staje się obiektem inspiration porn na co dzień. Relacjonuje rozmowy z nieznajomymi, którzy (w dobrej wierze) dziękowali jej za inspirację, choć nie robiła nic niezwykłego - podobnie jak oni jechała metrem. Young podkreśla jednocześnie inny opresyjny, a trudny do zauważenia dla osoby sprawnej aspekt tego rodzaju interakcji: oczekiwanie wdzięczności i radosnego uśmiechu jako reakcji na ową (pozorną) afirmację.

51 B. Haller, J. Preston Confirming Normalcy 'Inspiration Porn' and the Construction of the Disabled Subject?, w: Disability and Social Media. Global Perspectives, eds. K. Ellis, M. Kent, Routledge, London-New York 2017, s. 43.

52 Tamże.

53 J.S. Clogston A Theoretical Framework for Studying Media Portrayal of Persons with Disabilities wystąpienie konferencyjne podczas Annual Meeting of the Association for the Education in Journalism and Mass Communication, Washington, DC 1989; Disability coverage in 16 newspapers. Louisville, KY: Advocado Press199o - podaję za B. Haller, J. Preston Confirming Normalcy..., S. 42. 
Jej podważenie lub odrzucenie są niemalże nie do pomyślenia - niepełnosprawny ma być pogodny i ciepły.

Kategoria inspiration porn w zaproponowanym przez Stellę Young kształcie jest na granicy dyskursu potocznego (będąc aktywistycznym instrumentem podnoszenia świadomości) i akademickiego. Mimo że doczekała się krytycznej refleksji54, pozostaje poręcznym narzędziem opisu praktyk uprzedmiatawiających niepełnosprawnych.

\section{Alternatywne dyskursy: narracyjna proteza}

Kategoria narracyjnej protezy jest analitycznym narzędziem pozwalającym na ocenę i krytyczną refleksje nad reprezentacją niepełnosprawności w narracjach literackich i filmowych. Wprowadzili ją David T. Mitchell i Sharon L. Snyder w książce Narrative Prosthesis. Disability and the Dependencies of Discourse ${ }^{55}$ do opisu zastosowania niepełnosprawności jako łatwego w użyciu narzędzia metaforycznego i figury ułatwiającej konstrukcję narracji. Autorzy używają jej, gdy niepełnosprawność jest przedstawiana jako sytuacja szczególna i kryzysowa oraz zestaw stereotypowych cech, gdy nie uwzględnia się jej społecznej, kulturowej i historycznej złożoności, a jej uproszczona i instrumentalnie potraktowana wizja jest siłą wytrącającą z porządku. Jako taka, niepełnosprawność sygnalizuje opór wobec wtłaczania bohatera w społeczne normy i wymogi czy rozdźwięk między obciążającym ciałem a efemerycznym wymiarem umysłu. Pełnosprawne ciało nie jest w narracjach literackich czy filmowych w ten sposób obciążone, jest transparentne, natomiast niepełnosprawne sygnalizuje zestaw koncepcji i idei zogniskowanych wokół ograniczeń fizyczności. Niepełnosprawność jest wykorzystywana więc jako uzewnętrznienie motywacji bohaterów i skrypt umożliwiający interpretację ich zachowań.

Narracyjna proteza jest kategorią krytyczną: proteza zastępuje element, którego ciału brakuje a który potrzebny jest do jego sprawnego działania, narracyjna proteza zaś zastępuje elementy, które powinny znaleźć się w narracji, jak np. uzasadnienie poczynań postaci czy wiarygodny obraz rzeczywistości. Zastosowanie narracyjnej protezy jest uzupełnieniem tego braku

54 J. Grue The Problem with Inspiration Porn: a Tentative Definition and a Provisional Critique, „Disability \& Society" 2016 No. 31:6, s. 838-849.

55 D.T. Mitchell, S.L. Snyder Narrative Prosthesis. Disability and the Dependencies of Discourse, The University of Michigan Press, Ann Arbor 2000. 
przez rozwiązanie sztuczne, zewnętrzne wobec tkanki narracji. Kategoria ta wskazuje zatem na niepełnosprawność tekstów, które takie rozwiązanie narracyjne stosują. Oto teksty instrumentalnie wykorzystujące niepełnosprawność same okazują się kalekie. Mitchell i Snyder sami jednak łapią się w zastawioną przez siebie pułapkę: niepełnosprawność tekstu ujawnioną kategorią protezy oceniają negatywnie jako brak i upośledzenie. Tym samym autorzy reprezentujący kulturowy i społeczny model niepełnosprawności stosują do opisu „kulejących” narracji model medyczny, przeciw któremu występują. Omawiane przez autorów narracje są niejako patologizowane. Propozycja Mitchella i Snyder weszła jednak do kanonu studiów nad niepełnosprawnością.

\section{Zmiana języka, odzyskiwanie znaczeń}

Oprócz wprowadzania nowych kategorii studia nad niepełnosprawnością wskazują na dyskryminujący i opresyjny charakter słów, którymi do tej pory opisywano niepełnosprawność, jak kaleka (cripple), warzywo (vegetable), opóźniony/opóźniona (retarded, retard), ułomny/ułomna (lame, invalid ${ }^{56}$ ) czy dziwoląg (freak). Zwraca się uwagę nie tylko na poszczególne słowa, ale i na szersze praktyki dyskursywne przedstawiające osoby niepełnosprawne jako pasywne „ofiary choroby”, co może się przekładać na przekonanie o ich nieporadności w kontekście społecznym czy politycznym. Szczególnie przewrotne jest określenie „przykuty do wózka inwalidzkiego”/"skazany na wózek inwalidzki" (wheelchair bound, confined to a wheelchair). Badacze zajmujący się niepełnosprawnością podkreślają fałszywe założenie o opresyjnym charakterze wózka inwalidzkiego, który jest postrzegany jako ograniczenie użytkownika, więzienie $^{57}$, znak osobistej tragedii. Tymczasem dla wielu niepełnosprawnych użytkowników wózek jest prawdziwie emancypującym instrumentem pozwalającym na wygodne przemieszczanie się i niezależność. W 1996 roku Mary Tremblay opublikowała artykuł zbierający archiwalne dokumenty i wspomnienia kanadyjskich weteranów II wojny światowej, którzy w procesie rehabilitacji zostali wyposażeni w wózki inwalidzkie nowej generacjị ${ }^{58}$,

56 W przeciwieństwie do polskiego słowa inwalida, invalid ma wyraźnie negatywną wymowę jako przeczenie słowa valid - ważny, słuszny, prawidłowy. 
jednak rehabilitujący ich personel był zdeterminowany, by używali kul. Rehabilitowani żołnierze, pokonujący z trudem kilka metrów o kulach, szybko zdali sobie sprawę, że nowe wózki dają im o wiele większą mobilność przy mniejszym wysiłku. Autorka cytuje jednego z rozmówców: „Ludzie szybko zorientowali się, że chodzenie nie jest niezbędne", inny z weteranów przyznaje, że zmuszanie pacjentów do nauki chodzenia niemiłosiernie wydłużało proces rehabilitacji ${ }^{59}$. Gdy zatem przyjąć perspektywę użytkownika, wózek nie zawsze jest instrumentem niepożądanym. Badacze wskazują, że wyżej wymienione uprzedzenia (jak prymat chodzenia nad korzystaniem z wózka) są nie mniej opresyjne niż bariery architektoniczne ${ }^{\mathbf{6 0}}$.

Kolejną poddaną niuansowaniu kategorią jest sama niepełnosprawność. Za nieadekwatne (choć nieobraźliwe) uznano określenie „niepełnosprawny”, sugerując zastąpienie go sformułowaniem „osoba z niepełnosprawnością”. Przesunięcie to ma na celu umieszczenie osoby, nie jej kondycji, na pierwszym miejscu i uniknięcie definiowania niepełnosprawnych przez ich stan. We współwydawanym przez PFRON czasopiśmie „Niepełnosprawność - zagadnienia, problemy, rozwiązania” w 2013 roku Dariusz Galasiński uzasadnia i promuje użycie nowego sformułowania, wskazując przede wszystkim na jego niestygmatyzującą naturę ${ }^{\mathbf{6 1}}$.

Ciekawym przypadkiem jest słowo cripple - kaleka. Niegdyś służyło do neutralnego określenia osoby niepełnosprawnej ruchowo. Na początku XX wieku zaczęto go używać w półświatku związanym z żebractwem oraz jako slangowego synonimu przymiotnika „łatwy”62. Dziś słowo cripple ma wyraźnie obraźliwe brzmienie i stało się wyrazem nie-do-użytku, podobnie jak rzeczownik nigger (czarnuch). Początkowo obydwa były używane przez przedstawicieli grupy dominującej (sprawnych, białych) jako określenia neutralne. Jednak w miarę rozwoju ruchów związanych z prawami obywatelskimi rozpoznano je jako uwłaczające społecznościom, które były nimi opisane, przez związanie ich z dyskryminującymi i opresyjnymi wartościami i praktykami.

(2), s. 149-169.

59 Tamże, s. 159.

60 M. Davidson Universal Design: The Work of Disability in an Age of Globalization, w: The Disability Studies Reader, 2006, s. 119.

D. Galasiński Osoby niepełnosprawne czy z niepełnosprawnościq̨?, „Niepełnosprawność - zagadnienia, problemy, rozwiązania" $2013 \mathrm{nr}$ IV (9).

62 Crip Keywords for disability studies, ed. R. Adam i in., New York University Press, New York-London 2015, s. 140. 
Można jednak zaobserwować ich przewrotne zawłaszczenie. W latach 70. wraz z włączeniem się niepełnosprawnych w walkę o prawa obywatelskie w Stanach Zjednoczonych i Wielkiej Brytanii termin cripple zaczął być używany przez osoby niepełnosprawne jako wyraz przynależności tożsamościowej. Używany był ironicznie lub wręcz prowokacyjnie, w odpowiedzi na przeszłe, opresyjne podejście do niepełnosprawności, ale także nowy, ugrzeczniony i politycznie poprawny język. Posługiwanie się tym terminem ma sztubacki, przekorny charakter. Jest sygnałem wewnątrzgrupowej perspektywy, silnej tożsamości i aktywistycznej postawy. Jak pisze Joseph P. Shapiro, słowo cripple „jest jak zaciśnięta, wzniesiona pięśćn"

Przykładami autodefinicji przez termin cripple są blogi: Bad Cripple ${ }^{64}$, prowadzony przez Williama Peace, sparaliżowanego antropologa, Smart Ass Cripple ${ }^{65}$, czy żeńska grupa teatralna Wrycrips ${ }^{66}$. Aktor Mat Fraser prezentuje swoje zmienione przez fokomelię ciało w szczególnej formie burleski: criptease. To interesujące szczególnie transgresyjne przecięcie dwóch tabuizowanych formuł: niepełnosprawności, której nie przykrywa ubranie, i erotyki. Kalectwo Frasera z jednej strony czyni go niepełnosprawnym, ale jego silne, atletyczne, wykonujące szpagaty ciało jest bez wątpienia bardziej sprawne niż przeciętne i w ten sposób kwestionuje kategorię niepełnosprawności jako takiej. Można też wspomnieć o inicjatywie \#CripTrek na Twitterze, gdzie niepełnosprawni fani StarTreka usiłowali w 2016 roku zasygnalizować stacji CBS, że oczekują większej reprezentacji niepełnosprawności w nowych odcinkach serialu ${ }^{67}$.

Podobnie jak nigger, cripple jest skrajnie insiderskie. Nancy Maris w eseju On Being a Cripple ${ }^{68}$ stwierdza: „Nigdy nie określiłabym kogoś innego kaleką. To określenie, które wybieram dla siebie". Autorka wskazuje na jego niewygodny charakter. Simi Linton podkreśla jego krytyczny potencjał - przez

63 J.P. Shapiro No Pity: People with Disabilities Forging a New Civil Rights Movement, Times Books, New York 1993.

64 Zob. http://badcripple.blogspot.com/(9.08.2016).

65 Zob. http://smartasscripple.blogspot.com/ (9.08.2016).

66 Więcej na blogu grupy: http://wrycrips.blogspot.com/ (9.08.2016).

67 Zob. https://disabilityvisibilityproject.com/2016/08/23/91-criptrek-twitter-chat/ (30.08.2016).

68 N. Mairs On Being a Cripple, w: Plaintext:Deciphering a Woman's Life, University of Arizona Press, Tucson 1986. 
transgresję staje się ono narzędziem indywidualnego, ale i politycznie zorientowanego komentarza do społecznej opresji, gdyż pozwala ją nazwać ${ }^{69}$.

\section{Podsumowanie}

Studia nad niepełnosprawnością są dziedziną akademicką o prawie trzydziestoletniej tradycji. Doczekały się zarówno klasycznych tekstów, jak i krytyki, powoływane są ośrodki badawcze, kierunki studiów, publikowane podręczniki. Z powodzeniem wprowadzają mniejszościową tematykę do dyskursu akademickiego: w programach konferencji i zjazdów coraz powszechniej uwzględnia się zagadnienie niepełnosprawności i zdaje się, że weszła ona do kanonu tematów związanych z tożsamością, obok kobiet czy mniejszości. Należy jednak stwierdzić, że bardziej ociężale postępuje pluralizacja uprawiających naukę: nawet na konferencjach poświęconych niepełnosprawności większość prezentujących to osoby sprawne, mimo że kluczowi przedstawiciele studiów nad niepełnosprawnością sami należą do społeczności niepełnosprawnych.

W Polsce w praktyce akademickiej nadal dominuje podejście medyczne, pedagogiczne i pomocowe, a studia nad niepełnosprawnością są dopiero wprowadzane na arenę. W 2015 roku Uniwersytet Łódzki zorganizował międzynarodową, poświęconą niepełnosprawności konferencję Negotiating Space for (Dis) ability in Drama, Theatre, Film and Media, na którą zaproszono znanych badaczy studiów nad niepełnosprawnością: Davida T. Mitchella i Rosemarie Garland-Thomson. Nieco więcej dzieje się na pokrewnym polu studiów nad głuchotą - na Uniwersytecie Warszawskim działa Pracownia Lingwistyki Migowej, w 2012 roku w Łodzi odbyła się konferencja Deaf Studies w Polsce, której pokłosiem jest dostępna w sieci publikacja ${ }^{70}$. Opóźnienie dziedziny w Polsce - czy jej praktycznie jeszcze niezaistnienie - z jednej strony jest konsekwencją zapóźnienia rodzimej akademii w przepracowywaniu zachodnich koncepcji, z drugiej zaś pewnego przesunięcia cywilizacyjnego. Polskę ominęły ruchy społeczne drugiej połowy XX wieku emancypujące kobiety, mniejszości etniczne i seksualne czy w końcu osoby z niepełnosprawnościami. Po dekadach docierały one do nas, poczynając od ruchów najsilniejszych, kobiecych i mniejszości etnicznych w latach 9o., przez ruchy mniejszości

69 S. Linton Reassigning Meaning, s. 165.

70 DeafStudies w Polsce, red. M. Sak, Polski Związek Głuchych, Łódź 2014, http://www.pzg.lodz.pl/ attachments/article/394/Deaf\%20Studies\%20w\%20Polsce\%2otom\%2ol.pdf(6.11.2016). 
seksualnych na przełomie wieków. W 1995 roku Davis postulował, że niepełnosprawność jest brakującym elementem triady: rasa, klasa, płećn . Być może właśnie nadchodzi czas wypełnienia tej luki i zaadaptowania na polskim gruncie studiów nad niepełnosprawnością.

\section{Abstract}

\section{Magdalena Zdrodowska}

JAGIELLONIAN UNIVERSITY (CRACOW)

Between Activism and Academy: Disability Studies

This article outlines the history and theoretical foundations of disability studies a discipline that remains little known in Poland. Unlike medical and pedagogical paradigms, the social and cultural model does not see disability as an illness or a personal tragedy, but thinks about it in terms of identity and of socially negotiable concepts, attitudes and values. Zdrodowska situates disability studies in the context of Modernist redefinitions of norms as well as the process of medicalization that marked the twentieth century. The article's main focus is on the discipline's functioning in both academic frameworks and in social and political spheres. To illustrate the shift in perspective proposed by disability studies, Zdrodowska discusses the notions of ablism, inspiration porn as well as narrative prosthesis.

\section{Keywords}

disability studies, humanities, representation, history of science, identity

71 L. Davis Enforcing Normalcy, s. 1. 